\title{
Consumer Protection in Peru: Origins, Evolution, and Main Regulatory Influences
}

\author{
C. Carranza Álvarez ${ }^{1}$ (D) O. A. Alcántara Francia²
}

Received: 3 January 2022 / Accepted: 4 January 2022 /Published online: 8 February 2022

(C) The Author(s), under exclusive licence to Springer Science+Business Media, LLC, part of Springer Nature 2022

\begin{abstract}
In the following text, the authors address the origins and evolution of consumer protection in Peru, as well as highlighting the main regulatory influences of the current 2010 Consumer Protection and Defence Code with regard to consumer sales (defective products), and the regime of abusive clauses, to which is added a reference to protection of personal data.
\end{abstract}

Keywords Consumer regulations $\cdot$ Defective products $\cdot$ Abusive clauses $\cdot$ Personal information

The following lines present the development of consumer protection in Peru, since the distant norm of the 1979 Constitution that concisely declared the interest of the State in promoting consumer protection until the current protective legal regime. It is also shown that the influences of foreign law-in particular, those from European law-served to structure the main features that compose consumer law in Peru, with special emphasis on sales to the consumer (defective products) and on disciplining abusive clauses, to which is added a reference regarding protection of personal data.

The social, political, and economic environment that has accompanied the course followed by consumer law does not go unnoticed in our explanation, since there is no doubt that protective legislation is fed and demonstrates its effectiveness or otherwise precisely from that very environment. As protective legislation also depends on the political will of those who have the responsibility to guide the destiny of a country, perhaps this explains why the consumer defence movement in Peru began to take root at the end of a long dictatorial period and within the framework of a new political charter.

Translated by Laís Bergstein, Partner, Dotti e Advogados, email: lais@dotti.adv.br

C. Carranza Álvarez pcdececa@upc.edu.pe

O. A. Alcántara Francia oalcanta@ulima.edu.pe

1 Faculty of Law, Peruvian University of Applied Sciences, Lima, Peru

2 Faculty of Law, University of Lima, Lima, Peru 
Thus, together with the development of legal concepts, the authors will refer to all those necessary passages in our national history that will allow the reader a panoramic view of backgrounds and the path followed by consumer protection (and consumer law) throughout of the years. Finally, in the last part of this article, some concluding notes are included. These are accompanied by the corresponding references and sources.

\section{Origins and Evolution of Consumer Legal Protection in Peru}

The introduction to this article suggests that consumer protection and defence in Peru began with the 1979 Constitution, which inaugurated a new period of democratic life. However, it is possible to trace the legislator's intent since the previous Political Charter of 1933, which, although it did not include any rule referencing the figure of the consumer, contained various provisions referring to the consumer indirectly. That was a turbulent time, with the authoritarian government of President Augusto B. Leguía, who directed the destiny of the country for 11 years (1919-1930), which came to an end following a military revolt led by Commander Luis M. Sánchez Cerro, in 1930. Sánchez Cerro's accession to the presidency coincided with the election of a Congress that, as constituent, would have the mission of delivering a new Constitution to the country. This was sanctioned in 1933 - shortly before Cerro's assassination - and was nothing more than a "bad copy of the 1920s," and "although it lasted a long time, it lived in a state of precariousness, with authoritarian governments and various coups d'état" (García \& Eto, 2016, pp. 45-46). This Constitution strengthened the powers of the national assembly; created a popularly elected chamber of deputies next to the Senate; distributed the territory in departmental councils aiming for decentralization, which was never put into practice; increased and perfected so-called "social guarantees"; and introduced an electoral system that to this day is maintained, although with variations (García \& Eto, 2016, pp. 45-46).

Together with these novelties, the authors would highlight the provisions that are indirectly designed in favour of consumers, even if they did not yet appear as such on the legal scene. An example of this effect is Article 13, which projects the creation of a state agency in order to control the activity of banking companies; Article 16, which prohibits monopoly and industrial and commercial hoarding; Article 28, which reserves to the State the power to set maximum interest for cash loans; Article 9, which limits collection of fares for passage and freight to the national currency; Article 40, which recognizes freedom of commerce and industry, subject to requirements and guarantees, and to limitations and reservations for reasons of "security" or "public necessity"; while Article 50 obliges the State to take care of public and private health through enactment of hygiene and sanitary control laws (Carranza, 2017, p. 176).

Stiglitz asserts that development of consumer protection legislation and policies in Latin American countries "could not have originated - as in Europe - in the 1970s, since without stable democracies, during authoritarian regimes, of course, a social, cultural and economic transformation such as the one represented by the consumer protection movement was not feasible" (Stiglitz, 2013, p. 23). This explains why in the years following the 1933 Constitution, and until 1979, no attention was paid to protection of national consumers, even though news was already abroad of the appearance of a whole movement oriented to this end, both in North America and in Europe.

In fact, the decades that followed-between 1930 and 1979-were periods marked by democratic instability, strengthening of State intervention in the economy, implementation 
of agrarian reform that became a resounding failure, nationalization of companies, and inflationary peaks that ended up affecting consumption. However, some official figures indicate otherwise. For example, the 1970 report of the Central Reserve Bank of Peru (BCRP) points out - only for that year, under a military dictatorship — an increase in gross domestic product of $7.5 \%$ due to recovery of the industrial, fishing, agricultural, and construction sectors; growth in exports (17.1\% compared to the previous year); while imports of consumer goods decreased by $2.3 \%$ and, of these, those of non-durable consumer goods by $1 \%$, and of durable consumption by $7.9 \%$. Similarly, a decrease in imports of raw materials $(0.8 \%)$ is also indicated. Turning to the consumer price index, compared to the immediately previous year, a slight increase is registered for food and beverages, housing, furniture, and the like (p. 5). Up until 1975, a moment that would mark the beginning of the end of dictatorship and a period of transition-which would include convening a Constituent Assembly (the outcome of which was the 1979 Political Charter) and the call for free general elections - the situation would not be much different: a reduction in mining production of $12.2 \%$; an increase in private consumption of only $2.4 \%$, which meant a decrease in growth of $75.5 \%$ compared to 1973 and 1974; while the cost of living rose by $23.6 \%$ compared to the previous year, due to elimination of subsidies for some food and fuel products and a rise in international prices, without increasing real average income for workers (BCRP Report, 1975, p. 40 ff.).

The beginning of the 1980s meant the inauguration of a new democratic period led by President Fernando Belaúnde Terry, who would govern under the new Constitution. This is the Charter that constitutes the starting point of the consumer-protection State by declaring in the last part of its Article 110 that "[t]he State defends the interest of consumers," and the framework for issuance of the first regulation aimed at consumer protection in 1983: Supreme Decree No. 036-83-JUS 1983.

This decree was issued in response to "the critical economic situation" that the country was suffering, which prompted the government to "dictate extraordinary measures in economic matters in defence of the interest of consumers, in accordance with Article 110 of the Political Constitution of the State," as its first statement reads. This rule was contemporaneous with the final phase of a climatic phenomenon (El Niño) that devastated a good part of the north and south of the country, and which entailed losses in infrastructure and production reaching almost one billion dollars, in addition to human lives. ${ }^{1}$

Among other aspects of this law, (1) the consumer is defined as anyone who acquires goods or services by verbal or written contract, without distinguishing the final destination of the acquisition or action outside the business or professional sphere, which later would be present in consumer legislation (Article 4.1); (2) price controls and subsidies are established in order to protect the consumer economy (Article 6); (3) certain rights are recognized in favour of the consumer, among which stand out the right to make advance payments with interest reduction on credit sales (Article 21), to request the return of sums overpaid (Article 23), alternatively, seek termination of the contract, reduction of the price, free repair of the product, or return of the price paid, without prejudice to compensation corresponding to the acquisition of various products and services (Article 24); (4) the right to demand invoices or proof of payment, among others derived from obligations imposed on the supplier (Article 25); (5) monitoring and application of protective regulation to be in the hands of a diversity of officials of all ranks: the Ministers (of Economy, Finance and

1 https://www.indeci.gob.pe/compend_estad/1997/6.2_fenom.pdf (access date 29 November 2021) 
Trade, of Education, of Agriculture, Fisheries, Energy and Mines, of Industry, Tourism and Integration, Transport and Communications, Health, and the Interior), mayors and councillors, prosecutors, political authorities and others designated by the Executive Power (Article 2); and finally (6) all of its provisions are considered a matter of public order (Article 1).

Undoubtedly, the circumstantial nature (and urgency) that surrounded the issuance of this regulation was the reason that it did not become the pillar of an authentic state policy in favour of Peruvian consumers, which would only come to fruition in subsequent years. This is so, among other things, because consumer protection was not entrusted to an agency specialized in the market, as is the case now, but to a variety of public entities of all kinds, which undoubtedly prevented the establishment of defined policies conducive to safeguarding the rights and interests of consumers. However, as will be seen later, it was that regulation which set the course for all consumer regulations issued later, although with much greater scope. The Consumer Protection Act, approved by Legislative Decree No. 716 1991, which annulled Decree No. 036-83-JUS 1983, responds precisely to this situation.

The 1980s ended with the economy being practically devastated by the populist policy of the government of President Alan García Pérez (1985-1990). The attempt to nationalize the banks contributed to high inflation rates, subsidies, a shortage of basic items, hoarding and speculation, as well as irresponsible management of state companies. Some figures can illustrate the situation at that time: In 1989, national production fell by $12 \%$ compared to the previous year, the agricultural sector by $4 \%$, and the manufacturing sector by $19 \%$. At the same time, annual inflation reached a cumulative variation of $2775.3 \%$ with a consequent increase in consumer prices and a decrease in the real income of dependent and independent workers by $50 \%$ and $23 \%$, respectively. All this was due to the "general environment of the economy and the wage policy adopted, which, despite having periodic readjustments in remuneration levels, failed to compensate for the high 'inflationary' rhythm, according to the national monetary authority" (BCRP Report, 1989, p. 9).

This forced the new administration - of President Fujimori, who governed the country from 1990 to 2000 - to promote a policy of economic reform consisting, for example, of opening the economy to private investment (national and foreign), privatization of state-owned companies, promotion of free competition in the market, consolidation of fiscal coffers, and elimination of the subsidies policy. Its highest point was 1993, with the promulgation of a new Constitution. Subsequent governments have happily managed to maintain this situation.

In a context like that described, it is not difficult to imagine that the field of consumption also enjoyed a positive impact. Thus, in 1991-within the set of regulations referred to above, and still under the protection of the 1979 Constitution-Legislative Decree No. 716 was issued. This was called the Consumer Protection Act.

Later, in 1992, the National Institute for the Defence of Competition and the Protection of Intellectual Property (INDECOPI) was created, an agency designed to control the market and to enforce consumer protection regulations, free competition, and advertising, among other related matters; and in 1993, a new National Constitution appeared on the scene. Its Article 65, in addition to indicating that the State defends the interest of consumers, recognizes their rights to information, safety, and health. In this period of incessant changes, it is also worth highlighting the creation of regulatory bodies, such as OSIPTEL (Supervisory Agency for Private Investment in Telecommunications), in 1991; SUNASS (National Superintendence of Sanitation Services), in 1992; OSINERG (Supervisory Agency for Investment in Energy and Mines, which in 2007 was renamed OSINERGMIN), 
in 1996; and OSITRAN (Supervisory Agency for Investment in Public Transport Infrastructure), in 1998.

There is no doubt that the turning point in consumer protection in Peru was given by adoption of the Consumer Protection Act (Ley de Protección al Consumidor, 1991), which, according to qualified national doctrine, "gives an organic character, with a certain order and technical criteria to the legal treatment of consumer rights" (Durand, 2007, p. 130), far exceeding its predecessor norm.

Among the most important aspects regulated by the Consumer Protection Act, the following stand out: (1) a definition of consumer based on the criterion of the final destination of the acquisition, which would later (in 2008, by means of an amendment introduced by Legislative Decree No. 10452008 to Supreme Decree No. 039-2000-ITINCI, Single Ordered Text of the Consumer Protection Law of 1991) become that of acting in a field outside the scope of a business or professional activity; (2) protection of the consumer within the framework of the social market economy regime established in Article 58 of the 1993 Constitution and under the protection of the pro-consumer principle; (3) enumeration of consumer rights in the market (information, security, and the like); (4) marking the obligations of suppliers and infringement levels; and (5) designation of competent bodies for the defence of consumer rights. This task was initially allocated to district councils (of the place where the business establishment or production plant is located) and the Ministry of Industry, Internal Commerce, Tourism and Integration, through its General Directorate for Consumer Defence of the Internal Commerce sector. Later, it was reallocated to the decision-making bodies of INDECOPI, a state agency created in November 1992 by Decree of Law No. 25868 1992, which constitutes a specialized public body with the legal status of internal public law, with functional, technical, economic, budgetary, and administrative autonomy, dependent on the Presidency of the Council of Ministers. As of today, it is this authority that oversees administrative procedures for consumption and management of national policy for consumer defence.

Adoption of the Consumer Protection Act and creation of INDECOPI were joined-as indicated - by one of the most important legislative milestones of that decade: approval of a new Constitution in 1993. The opinion of authoritative doctrine, which the authors share, is that the 1993 Constitution "has contributed (...) to the economic growth of the country," by "giving private individuals greater freedom so that they are the ones who, with their efforts, create wealth," where "[ $\mathrm{t}]$ he State, for its part, plays a fundamental role finding itself under the inalienable obligation to promote an attractive scenario for investment, ensuring at all times the dignity and rights of those least favoured in society" (Álvarez, 2014, p 269). Title III of the 1993 Constitution, referring to the economic regime, is worth highlighting.

This constitutional section (namely, Title III of the 1993 Constitution) consolidated the major economic guidelines that had been set by the government administration at that time. Thus, among other provisions, it (1) proclaims that private initiative is free and is exercised within the framework of a social market economy (Article 58); (2) affirms that the State promotes creation of wealth and guarantees the freedom for work, business, commerce and industry (Article 59); (3) recognizes economic pluralism and the coexistence of diverse forms of ownership and enterprise (Article 60); (4) establishes the subsidiary role of the State in the economy (Article 60, paragraph 2); (5) facilitates and oversees free competition (Article 61); (6) highlights freedom to contract (Article 62); and (7) affirms that national and foreign investments are subject to the same conditions (Article 63).

In the scenario of an economy open to national and foreign investments and that promotes free competition, incorporation of a legal rule to institute consumer defence was 
necessary, since " $[t]$ he consumer is a central actor in the dynamics of the correct functioning of competing markets," since their actions "determine the success or failure of a company and, in turn, guide the action of producers, suppliers or traders of the goods or services available" (Indecopi, 2005, p. 32). This is precisely what appears in the first part of Article 65, which reiterates the declaration that already existed in the 1979 Constitution (defence of the interest of consumers and clients by the State); however, it innovates by including two separate rights of special protection, such as the right to information on goods and services and the right to health and safety of the population. This constitutional provision must be read in tandem with the first Article of the Constitution, which places defence of the human person and respect for their dignity as the supreme goal of society and the State.

The Constitutional Court has held, concerning Article 65, that "the estimated judgement and the logical judgement derived from the State's conduct in the matter, have as a protective horizon the defence of the interests of consumers and users," this " $(\ldots)$ by means of the consecration of a subjective right that recognizes the power of defensive action of consumers in cases of transgression or ignorance of their legitimate interests, demanding specific action from the State when there is some form of threat or effective affectation of their rights, including the capacity to act against the provider itself " (STC Exp. $\mathrm{N}^{\circ}$ 0008-2003-AI/TC, of 11 November 2003, among other judgments), and which also implies a plurality of principles, such as pro-consumer interpretation, banning abuse of the right of real isonomy, transparency, truthfulness, in doubt pro-consumer, and the pro-associative principle (STC Exp. N ${ }^{\circ} 3315-2004-A A / T C, 17$ January 2005).

In this regard, as already observed, "consumer protection thus becomes the cornerstone of the social market economy regime assumed by the country, (...); in the objective that colours the performance of the State at all its levels, whether through the Executive, Legislative and Judicial Powers, Public Administration and regulatory bodies; an imperative that radiates to the different areas where the consumer tends to interact with the provider of goods and services; and even in the interpretation of legislation that concerns him, directing it to everything that favours him; all this within the framework of the defence of the human person and respect for their dignity, which constitute the supreme goal of society and the State (...)" (Carranza, 2017, p. 179).

Since its entry into force, the Consumer Protection Act has undergone successive modifications, which have improved its content. From among all of them stands out the one produced by Legislative Decree No. 1045, published in the official newspaper El Peruano on 26 June 2008, called the Complementary Law for the Consumer Protection System. Here again a rule responds to a particular context of national economic life, such as the signing of the Free Trade Agreement with the United States of America (USA). The main incentive for the agreement was the tariff preferences regime granted to the country since 1991. The agreement was signed on 12 April 2006 in Washington and entered into force on 1 February 2009, establishing specific rules on technical barriers to trade, trade protection, financial services, intellectual property, and e-commerce, among others.

The signing of the US-Peru Trade Promotion Agreement required the Peruvian State to review and modify regulations in the sectors involved to adapt them to the new commercial scenario. In particular, one of the regulations that underwent this exercise was the Consumer Protection Act by means of the aforementioned Decree because, as the third paragraph of its recitals stated, "the proposal for reform of the current Consumer Protection Act obeys the urgent need to provide the country with an institutional framework that guarantees effective protection of consumer rights, in the new environment of consumer relations that will result from the prompt implementation of the Peru - United States of 
America Trade Promotion Agreement." Thus, among other provisions, this rule (1) subjected the notion of consumer to actions taken in a field outside professional or business practice; (2) exceptionally incorporated micro-entrepreneurs as consumers; (3) added new assumptions of coercive commercial practices; (4) contemplated new abusive methods, and (5) established criteria for graduated administrative sanctions against reported suppliers; furthermore, in addition to these modifications, other rules were established on (1) price rounding, (2) product labelling, (3) remote offer systems (call centres, telephone calls, text messages, and so on), (4) lines of credit and information on deposits, (5) general rules on consumer contracts (abusive clauses and others), and (6) medical services in health establishments, and the like.

The Consumer Protection Act came to an end because at the initiative of then President García Pérez (2006-2011) — who in his message to the nation on 28 July 2009 called on the national assembly to adopt a Consumer Code for the country-discussions began on what would finally become the Consumer Defence and Protection Code, which entered into force in October 2010.

\section{The 2010 Consumer Defence and Protection Code (CPDC)}

The current Consumer Protection and Defence Code (CPDC), which replaced the Consumer Protection Act, approved by Legislative Decree No. 716, has the late President Alan García Pérez as its main mentor, since its preparation and subsequent approval began on his own initiative and within his administration. On 2 September 2010, the CPDC was published in the official journal El Peruano and its validity was set for 30 days after that, thanks to the period of vacatio legis established in its Fourth Final Complementary Provision, except for Articles 36 and 37, which followed the CPDC into effect 180 days thereafter, with Subchapter III of Chapter III of Title V (summary procedure) taking effect 60 calendar days after Articles 36 and 37.

Unfortunately, promulgation of the Code was not unanimously welcomed, since shortly after the appearance of its text, several academic voices spoke out against its approval. Thus, it was said that " $[\mathrm{t}]$ his law has no greater support or current need (...), and ironic as it may seem, it breaks a basic guiding function of the State in its policy with consumers, such as consumer education, promotion of a reasonable, informed, attentive and insightful consumer, as well as development of a culture of quality of products and services, rather than paternalistic consumer protection (...)" (Fernández-Maldonado, 2010, p. 27), to the point of being accused of being excessively interventionist, of unnecessarily incorporating public policies when the correct thing to do would have been to put them into practice "through institutional measures," described as "extensive and unsystematic" (Zúñiga Palomino, 2010, p. 37-43).

However, the authors align themselves with authorized national doctrine in the sense that " $[t]$ his normative body has the merit of condensing in a single document a series of provisions of both a legal and administrative nature that in one way or another regulated consumer rights." Therefore, "it gives an organic character, with a certain order and technical criteria to the legal treatment of consumer rights and its sole nomenclature shows where it points from the legal point of view in this matter for the future" (Durand, 2016, p. 95).

The CPDC was issued in a period of frank political, institutional, and economic stability. This is demonstrated by the smooth transition from one democratic government to another, and also by the economic figures of that time: Growth of the Peruvian economy by $8.8 \%$, GDP per capita amounted to USD 5,225, domestic demand expanded by $12.8 \%$, 
private consumption grew at a rate of $6 \%$, while the inflationary level showed a percentage of $2.08 \%$, according to information from the Central Reserve Bank of Peru (Memoria, 2010, p. 13-19). That good context managed to be maintained over time and served to deepen consumer defence policies, together with the regulation that the CPDC created.

Among some of the most relevant aspects of the CPDC are (1) an indication of the principles of consumer protection and defence (Article V of the Preliminary Title), (2) the approach of public policies to consumer protection (Article VI of the Preliminary Title), (3) incorporation of special rules regarding consumer contracts and sanctions in case of abusive clauses (Article 45 et seq.), (4) regulation of registration of consumer complaints (Articles 150, 151 and 152), (5) implementation of the summary procedure, processed in administrative channels for solution of minor consumer disputes (Article 124 et seq.), (6) incorporation of a specific section dedicated to collective consumer defence (Article 128 et seq.), and (7) creation of a National Integrated Consumer Protection System (Article 132 et seq.), and the National Council for Consumer Protection (Article 133), among others.

All this regulation was accompanied by growth of the Peruvian economy and increasingly complex transactions carried out during the following years; the increase in private consumption; commercial expansion, which resulted in the proliferation of shopping centres, supermarkets, department stores, and with it consumer loans; the transformation of consumer habits, now oriented to recreation, culture, and entertainment; the increase in population, which drove the boom in certain markets, such as real estate, automotive, and finance (for obtaining loans for the purchase of homes and automobiles); and the massification of internet access and cable television. In short, expansion of the market, which in turn also triggered claims in all those areas of consumer action, was the framework for the issuance of Supreme Decree No. 006-2017-PCM 2017 (El Peruano, 2017) that approved the National Policy for Consumer Protection and Defence, which precisely accounts for this scenario (p. 6 corresponding to the numbering of the official gazette), which later resulted in the National Plan for Consumer Protection of 2017-2020, approved by Supreme Decree No. 024-2017-PCM 2017, published in the official gazette on 15 March of that year.

The plan's execution revolves around four strategic cornerstones: (1) education, orientation and dissemination of information; (2) protection of consumer health and safety; (3) mechanisms to prevent and resolve conflicts between suppliers and consumers; and (4) strengthening the Integrated National Consumer Protection System (see p. 17 of the publication of the official gazette).

Thus, throughout all these years, regulations for the national protection of consumers walked hand in hand with growth of the home economy, adapting to respond to the challenges imposed by an ever more complex market, but also updating itself, to offer responses to crisis situations. An example was the expedition of D.S. $\mathrm{N}^{\circ}$ 036-83-JUS 1983, mentioned above. Nowadays, with the experience of the global coronavirus pandemic (COVID-19), this has clearly done far more than changing the routines and habits of the population. In addition, it has restructured the shape of labour (from face-to-face to remote work), of communication (massive use of Zoom, Google Meet, Facebook virtual rooms, or live broadcasts through Instagram), and of education at all levels (virtual education through platforms, such as blackboard). The global pandemic has also changed how to start a business (increasing growth of internet businesses), to boost commerce (web pages or electronic applications), and to manage personal bank accounts (which has promoted the use of apps in cell phones and computing devices). Finally, COVID-19 has changed consumption patterns such as the trend in health care and disease prevention. These together could affect the recognized rights of consumers, who have received due warning, during the national emergency decreed by the government, in terms of consumer conflicts due to 
non-delivery of products purchased online, rescheduled and cancelled flights, theft of cellular equipment with applications from banking institutions, problems with information on health products and cleaning, educational services, hoarding and speculation of essential products, and so on. It is possible, then, that in the months and years to come, consumer law will necessarily have to adapt to all these challenges, in favour of the vulnerable in the market.

On the other hand, the Peruvian Consumer Code 2010 has not only been structured based on many of the rules and legislative figures that the previous Consumer Protection Act included but has also received the influence of those coming from foreign law, particularly European, as the authors will explain next.

\section{Regulatory Influences of The Consumer Defence and Protection Code 2010}

\section{The Rule Applicable to Defective Products}

The CPDC (Article 102) defines a defective product as one that does not offer the safety to which people are entitled, taking into consideration relevant circumstances, such as (1) the design of the product; (2) the way the product has been introduced to the market, including its appearance, the use of any brand, related advertising, and use of instructions or warnings; (3) its foreseeable use; and (4) the materials, content, and product condition.

The influence exerted by European law is undeniable, specifically Directive 85/374/ EEC of 25 July 1985, on the approximation of the laws, regulations, and administrative provisions of the Member States concerning liability for defective products. Indeed, the concept of a defective product is inescapably linked to safety, which is assessed based on the presentation of the product, the use that could reasonably be expected of it, and the moment the product was put into circulation (Article 6.1, Directive 85/374/EEC).

In contrast to the European directive, the Peruvian legislator considered importantin determining product defectiveness-the design and materials, content, or condition of the product. This rule is part of the set of legal provisions consolidated in the CDPC and that forms part of Legislative Decree No. 716, reviewed earlier. Its Article 32 established: "The supplier is responsible for damage caused to the physical integrity of consumers or to their goods due to defects in their products. A product is considered defective when it does not offer the safety to which people are entitled, taking into consideration all the circumstances, such as: (a) the design of the product; (b) the way in which the product has been placed on the market, including its appearance, the use of any brand, related advertising, or use of instructions or warnings; (c) the foreseeable use of the product; and, (d) the materials, content and condition of the product."

One aspect that deserves to be emphasized is that, in Peruvian consumer law, the applicable regime for defective products is mixed: administrative and civil. In the civil sphere, the general rules of strict civil liability for risk (Article 1970, Cc) apply. These grant compensatory protection to the affected consumer. This compensatory protection is exclusive to the judiciary, and Indecopi cannot compensate consumers, but can only apply the following contractual remedies for cases of non-performance or late, defective or partial performance: product repair or replacement, price reduction, contract termination, etc., all of which are provided for in the CPDC and fall under the exclusive competence of Indecopi. 
In administrative headquarters, the liability of the supplier or of the merchant is analysed in light of the suitability of a product or service reported as defective. In the terms of the CPDC, the supplier "is administratively responsible for lack of suitability, quality, unjustified risk or omission of defective information (...) in a specific product or service" (Article 104).

Directive 85/374/EEC establishes a strict liability regime in that "it constitutes a solid tool for protection of injured parties. However, in several circumstances the Directive allows producers to take certain calculated risks when selling innovative products. The producer will not be liable if it can demonstrate that: (1) the defect did not exist at the time the product was put into circulation; (2) the defect is due to conformity with the regulations issued by public authorities; or (3) the state of technological knowledge at the time the product was marketed made it impossible to discover the defect" (European Commission, 2018).

In contrast to the Community Directive, the Peruvian consumer law distinguishes between the type of responsibility assumed by a supplier of defective products and a supplier of defective services. In the first case, if a defective product causes damage to the physical integrity of consumers or to their assets, the supplier's or merchant's liability is objective (Article 101, CPDC, 2010). The only way to break the causal link occurs when the supplier "manages to prove the existence of an objective, justified and unforeseeable cause (...) due to unforeseeable circumstances or force majeure, in fact indicating a third party or the imprudence of its own affected consumer" (Article 104). Thus, in the case of automobiles that present defects shortly after being sold, the Consumer Protection Chamber (an administrative body of Indecopi that resolves consumer protection disputes at second and final instance) has indicated that "in accordance with the provisions of Article 104 of the Code, once an alleged failure has been proven, it is up to the supplier to demonstrate that said defect was not attributable to him, being exonerated from administrative responsibility if he succeeds in proving the existence of an objective, justified and unforeseeable cause that constitutes a rupture of the causal link due to unforeseeable circumstances or force majeure, in fact indicating a third party or recklessness by the affected consumer himself" (Resolution N ${ }^{\circ}$ 071-2014/SPC-INDECOPI: Exp. 001-2013/CPC-INDECOPI-CAJ; Resolution $N^{\circ}$ 0261-2014/SPC-INDECOPI: Exp. 002-2013/CPC-INDECOPI-CAJ).

Likewise, in the case of sale of defective computers, the Chamber stated "that the supplier is responsible to consumers for making available products that present operating defects, taking into consideration the following: (1) the consumer is the one who is in a situation of technical vulnerability vis-à-vis the supplier in a consumer relationship; (2) sale of a defective product does not meet the consumer's expectations; and, (3) it is the supplier who is in the best position to prevent the effects caused by unsuitable products available in the market, or who can reduce the costs that are caused in the most economical way possible" (Resol. N ${ }^{\circ}$ 102-2015/SPC-INDECOPI: Exp. 226-2013/CPC-INDECOPI-PIU). It should be noted that assumptions that involve development risks as causes of exemption from liability have not been foreseen by the Peruvian legislator.

In the second case, that is, the liability regime applied to a defective service provider, the analysis carried out by the administrative authority is different (we emphasize that resolution of consumer disputes is the exclusive competence of Indecopi, reserving the protection of compensation for the courts). In effect, the regime is not always of strict liability, and the suitability of the service can be evaluated based on the nature of the obligation contracted by the provider: if the obligation is to implement all means possible or if the obligation is to achieve a specific result (Article 104, CPDC, 2010). Thus, the liability regime can be objective or subjective. For example, in the case of delivery of a property built with a 
defective main bathtub (duly verified during inspection), the Consumer Protection Chamber declared that "according to the logic of the administrative procedures for consumer protection, once the defect has been proven $\neg$ either by evidence presented by the consumer or ex officio by the Technical Secretariat $\neg$ a supplier that aims to be exempted from responsibility must provide evidence that proves the breaking of the causal link or that he acted with due diligence" (Resolution No. 0092-2016/SPC-INDECOPI: Exp. 1005-2014/ CC2).

In court, the regulation itself establishes strict liability for defective products, in accordance with the provisions of Article 1970 of the Peruvian Civil Code (Article 101, CPDC, 2010). However, the liability regulated in that standard is based on the exercise of risky or dangerous activities (or products). This agreement, made by the Peruvian legislator since 1991 in Legislative Decree No. 716, has been criticised by doctrine on the basis that liability for defective products is based on the criterion of "defect," while the second is based on "created risk" (Espinoza Espinoza, 2012; Woolcott, 2001).

The truth is that, although in administrative headquarters the responsibility of a supplier of defective products or services is sanctioned by fines and application of contractual remedies in favour of the consumer (such as repair, replacement, or refund of what was paid), at the same time, the damage that these products could cause or defective services could generate constitutes compensation claims granted by civil judges. It should be affirmed that civil liability, in civil law, arising from defective provision of a service is assessed in the light of the regime of subjective liability.

Finally, regarding participation by more than one supplier located in different positions in the manufacturing-marketing chain, Directive 85/374 sanctions this assumption with joint and several liability, without limiting the right of each supplier to seek compensation against the manufacturer or distributor. The Peruvian legislator, faced with the same assumption, has also opted for joint liability (Article 101, CPDC, 2010). Like the Directive, it safeguards the right of each supplier to "claim against the one who supplied the defective product or originated the defect."

\section{The Legal Regime of Abusive Clauses, The "Black" and "Grey" List System, the Concept of "Abusiveness" and Planned Sanctions}

In general terms, it can be affirmed that the CPDC consists of a compilation of the jurisprudential heritage in administrative headquarters developed over almost twenty years (from the entry into force of the Consumer Protection Act, 1991). As indicated, the competent authority for sanctioning the provider (businessman or professional) is INDECOPI through its specialized bodies: the Consumer Protection Commission and the Specialised Consumer Protection Chamber. These are administrative bodies in charge of applying consumer law through management of administrative sanctioning procedures aimed at detecting regulatory infringement and applying financial penalties (fines) and/or corrective measures (refund of what was paid, repair of the good, substitution or replacement, and so on, while any claim for compensation is excluded, as this does not lie within the competence of Indecopi). Ordinary jurisdiction is reserved only for appeals for annulment lodged against the second instance decision of the Specialised Consumer Protection Chamber of Indecopi. This type of action is heard before the Administrative Chamber.

In 2010, the work of the Peruvian legislator focused on creating an organic body that would collect the jurisprudential criteria of the competent administrative authorities, but at the same time was connected to European consumerist scholars. At the time of the 
parliamentary debates leading to adoption of the CPDC, in the European Union, the Proposal for a Directive of the European Parliament and of the Council on Consumer Rights was under analysis (European Commission, 2008). According to this Proposal (which amended, among others, Directive 93/13/EEC on abusive clauses in contracts concluded with consumers), two lists were established in Annexes II and III: one, which considered behaviours deemed abusive in any circumstances (known, colloquially, as the "black" list), and the other, which contained a list of clauses "that should be considered abusive unless the merchant proves otherwise" (known as the "grey" list).

This Proposal for a Directive, from 2008, was accepted by the Peruvian legislator, its influence being reflected in Articles 50 and 51 of the CPDC, which incorporate the black list system (clauses abusive per se) and the grey list (clauses presumed abusive). However, it should be noted that the final text of Directive 2011/83/EU of the European Parliament and of the Council, of 25 October 2011, did not include Annexes II and III with the black and grey lists. Establishment of a black and a grey list is therefore ruled out, opting to maintain a clearly expressed list of clauses presumed abusive. This does not prevent Member States from adopting stricter protection measures in their national laws (that is, it leaves states free to adopt the dual list or single list system).

On the other hand, the concept of "unfairness" established in the CPDC is built from the idea of the existence of a contractual imbalance between the provider and the consumer (adherent), as does Directive 93/13/EEC (Article 3) on abusive clauses in contracts with consumers. The regulatory framework of the contract is an important element that shows the imbalance (Article 49) since it will be possible to evaluate the object of the contract (nature of the products or services), the circumstances at the time of entering into the contract, the information provided to the consumer (Becher, 2008), and, in general, all contractual clauses (in the same sense, Article 4 of Directive 93/13/EEC). The supplier assumes the burden of proving that the clause objected to was negotiated with the consumer.

The sanction imposed on a provider that includes any clause indicated in the "black" list is its absolute ineffectiveness. Within the list of clauses abusive per se, or black list, contained in Article 50 CPDC, are those that exclude or limit the responsibility of the provider or its dependents due to fraud or fault and those that transfer responsibility to the consumer due to the supplier's acts or omissions; clauses that empower the supplier to unilaterally suspend or terminate a contract, except for different legal provisions or the application of properly supported prudential regulations issued by the corresponding authority; clauses that empower the provider to terminate a contract without prior communication or to terminate a contract of indeterminate duration without a reasonable period of notice, except for a different legal provision or the application of duly supported prudential regulations issued by the corresponding authority; clauses that establish unilateral power in favour of the supplier to extend or renew the contract; that exclude or limit legal rights recognized as belonging to consumers, such as the right to make advance payments or prepayments, or to oppose the exception of non-compliance or to exercise the right of retention, consignment, among others; clauses that establish limitations with respect to the consumer on the power to oppose procedural exceptions, limitations on presentation of evidence, reversal of the burden of proof, among other rights concerning due process; clauses that establish the consumer's waiver to file a complaint for infringement of the rules of the Code; and in general, all clauses that are contrary to or in violation of rules of public order or of an imperative nature.

Reprehensible behaviour included in the "grey" list will be sanctioned with relative ineffectiveness (Article 52, CPDC, 2010). The second paragraph of this article states that a decision on non-application of grey clauses issued in administrative proceedings does 
not prejudice a decision that may be adopted in judicial or arbitration proceedings. Given that Indecopi has exclusive competence in consumer matters, the judicial actions referred to in the rule would be appeals for annulment against final decision brought by the "losing" party in administrative proceedings. On the other hand, consumer arbitration proceedings are not compatible with administrative proceedings, which means that consumers must choose the jurisdiction to which they wish to submit a dispute: either arbitration or administrative.

In the "grey" (express, provided for in Article 51 CPDC) list are those clauses in contracts that impose onerous or disproportionate obstacles for exercise of rights recognized as belonging to the consumer, such as clauses that allow the supplier to unilaterally modify the terms and conditions of a contract of continuous duration, to the detriment of the consumer, unless this is due to reasons expressed in the contract and the consumer enjoys the right to disengage from the contract without penalty; that establish automatic extension of the contract by setting an excessively short period for the consumer to express their wish not to extend it; that establish economic burdens or cumbersome procedures for complaining to the supplier, as well as those that establish cumbersome procedures for proceeding to repair an unsuitable product, or involve any prior act or action on the part of the consumer that makes it impossible to properly protect their rights; that allow the supplier to delegate performance of its service to a third party when the supplier was chosen for its individual qualities; or that establish that the supplier can unilaterally change the type of currency with which the contract was concluded, to the detriment of the consumer.

In this regard, in Resolution No. 078-2012/SC2-INDECOPI, of 1 January 2012, the Specialised Chamber for Consumer Protection extensively developed the notion of the abusive clause, its economic and legal basis in current market dynamics (which imposes mass contracting as a contracting scheme), clarifying that the purpose of classifying certain contractual clauses as abusive was to correct the informational asymmetry existing between suppliers and consumers through the imposition of a minimum standard of quality of the contract that improves a situation which the market cannot correct. The following requirements were established in the resolution to determine if facing with an abusive clause: when the clause (1) causes a disadvantage to the consumer; (2) is inserted in a contract that, interpreted as a whole, does not justify the disadvantage imposed on the consumer; and (3) creates a significant disadvantage, in the sense that it unbalances the relationship between the supplier's position and the consumer's position. It goes without saying that the regulation contained in the code constitutes an important advance in the fight against stipulations that only deepen the degree of vulnerability suffered by consumers in the consumer market.

\section{The Influence of European Law on Regulation of Personal Data Protection}

The issue of personal data protection — or "computer privacy," in the words of Ruíz Miguel (Álvarez, 2015, p. 53)—escapes the CPDC. However, given its close link-today more than ever-with the field of consumption, it is permissible to include a section on it, to highlight its connection with similar European regulations. Directive 95/46/EEC of the European Parliament and of the Council, of 24 October 1995, on the protection of natural persons about the processing of personal data and their free circulation, sets forth (Article 10) the right of each person (or consumer) to be informed when (1) data have been collected from an interested party and (2) data have not been collected from an interested party (Articles 10 and 11 of the Directive). In both cases, it seeks to guarantee transparency 
in the use of data as well as rights of access, rectification, and opposition of the interested party or owner of the data.

This Directive has let its influence be felt in Peruvian law, since Act No. 29 733, of 21 June 2011, regulates with enough precision the rights of holders of personal data, such as the right to information; the right of access to personal data; the right to update; the right to inclusion, rectification, and deletion; the right to prevent disclosure of data; the right to object; the right to objective treatment; the right to guardianship; and the right to be compensated (Articles 18 to 25). However, the right to be forgotten is not part of this catalogue. In European law, the starting point for its recognition is the STJCU-Google v. Costeja (2014). Peruvian law has also recognized the right for the first time in 2016 by administrative jurisprudence in the case of Google against a citizen who demanded removal of any information relating to the dismissal of his criminal case (Directorial Resolution No. 045-2015/JUS-DGPDP). As is the case in EU Member States (Article 28 of the Directive), the Peruvian regulation has created a control authority called the National Authority for the Protection of Personal Data (ANPDP), which oversees-initiating as a result of its status-disciplinary administrative procedures for alleged infringement of rules contained in the law. Among some notable cases resolved under this regulation is that involving the sanction of a transport company for not having registered its personal database of customers and their workers in the National Registry of Protection of Personal Data (Resolution No. 044-2015-JUS/DGPDP-DS of 31 July 2015). Likewise, a hotel was sanctioned for having processed personal information of its guests without their consent (Resolution No. 088-2016-JUS/DGPDP, of 11 September 2016). In the same sense, a company was sanctioned for having carried out processing of personal data related to the date of birth, profession, and wedding anniversaries of its clients without an authorised purpose and for carrying out non-essential or relevant data processing, contravening the principles of purpose and proportionality (Resolution $\mathrm{N}^{\mathrm{O}}$ 265-2016-JUS/DGPDP-DS, of 28 October 2016). More recently, a sanction was imposed on the company Domino's Pizza for having discovered, after an audit on its website, that they were processing the personal data of web users for purposes not linked to provision of the service and without their authorisation, as well as collecting data through web forms without informing customers what that data would be used for (Directorial Resolution No. 1530-2020-JUS/DGTAIP-DPDP, of 29 September 2020).

\section{Conclusion}

In the light of what has been reviewed along the previous lines, the authors conclude that similarly to what has happened in many countries in the same region, in Peru, consumer protection found favourable terrain for its development as of 1980, through the Constitution of the previous year, in a context of recovery of democratic life and some political, social, and economic stability. In previous years, no legislative initiative was aimed at discussing consumer regulations, even though consumer defence movements in the USA and Europe were already fighting for recognition of their rights. Unsurprisingly, the consumer protection regulations (from Supreme Decree No. 036-83-JUS to the current CPDC) "hold hands" with the economic and social transformations of the time in which it was issued, placing it in a favourable situation to respond to a national market in permanent growth, marked by the coexistence of increasingly complex transactions and claims by consumers affected by violation of their rights. 
However, it seems clear that any national policy aimed at consumer protection and defence necessarily requires an institutional framework that allows interaction between the various agents involved in promoting, monitoring, and executing initiatives of this type. Following this line of thinking, the current Consumer Protection and Defence Code of 2010 has been structured based on many of the features included in the previous Consumer Protection Act and the jurisprudential developments of the enforcement authority (INDECOPI), as well as receiving the influence of European regulations that, for a long time, have informed the national legal model.

Overall, the European influence on Peruvian consumer regulations has been felt, in a particular way, concerning the legal regime applicable to unfair terms, where the inclusion of two "black" and "grey" lists has been foreseen and the sanctioning of their absolute or relative ineffectiveness. In addition, the rules contained in the CPDC on liability for defective products undoubtedly follow European law: adoption of the objective liability regime or the rules on joint and several liability between different suppliers in the production and marketing chain for damage caused to the consumer are proof of this. In the same way, this has been felt in the processing of personal data that, in many cases, involves consumers; the Peruvian national standard, Law No. 29 733, closely followed Directive 95/46/EEC in the provision of rights that correspond to people with respect to their sensitive data.

\section{References}

Álvarez Caro, M. (2015). Derecho al olvido en internet: El nuevo paradigma de la privacidad en la era digital. Reus.

Álvarez Miranda, E. (2014). El modelo económico de la Constitución peruana. Ius et Veritas, 24(48), 256-269.

Banco Central de Reserva del Perú. (1970). Memoria del año 1970. https://www.bcrp.gob.pe/docs/Publi caciones/Memoria/Memoria-BCRP-1970.pdf (accessed 15 November 2020).

Banco Central de Reserva del Perú. (1975). Memoria del año 1975. https://www.bcrp.gob.pe/docs/Publi caciones/Memoria/Memoria-BCRP-1975.pdf (accessed 15 November 2020).

Banco Central de Reserva del Perú. (1989). Memoria del año 1989. https://www.bcrp.gob.pe/docs/Publi caciones/Memoria/Memoria-BCRP-1989.pdf (accessed 15 November 2020).

Banco Central de Reserva del Perú. (2010). Memoria del año 2010. https://www.bcrp.gob.pe/docs/Publi caciones/Memoria/2010/Memoria-BCRP-2010.pdf (accessed 15 November 2020).

Becher, S. (2008). Asymmetric information in consumer contracts: The challenge that is yet to be met. American Business Law Journal, 45(4), 723-744.

Carranza Álvarez, C. (2017). De la tutela constitucional del consumidor al reconocimiento de su vulnerabilidad. Primera exploración jurisprudencial. Revista de direito do consumidor, 114(26), 19-50.

European Comission. (2018). Informe de la Comisión al Parlamento Europeo, al Consejo y al Comité Económico y Social europeo sobre la aplicación de la Directiva del Consejo relativa a la aproximación de las disposiciones legales, reglamentarias y administrativas de los Estados miembros en materia de responsabilidad por los daños causados por productos defectuosos (85/374/CEE).

European Comission. (2008). Propuesta de Directiva del Parlamento Europeo y del Consejo sobre derechos de los consumidores (8 October 2008, COM(2008) 614 final.2008/0196(COD)). https://eurlex.europa. eu/LexUriServ/LexUriServ.do?uri=COM:2008:0614:FIN:ES:PDF (accessed 1 December 2020).

Durand Carrión, J. (2007). Tratado de Derecho del Consumidor en el Perú. Fondo Editorial de la Universidad de San Martín de Porres.

Durand Carrión, J. (2016). El Código de Protección y Defensa del Consumidor. Retos y desafíos para la promoción de una cultura de consumo responsable en el Perú. Revista de actualidad mercantil, 4, 94-135.

Espinoza Espinoza, J. (2012). Derecho de los consumidores. Editorial Rhodas.

Espinoza Espinoza, J. (2020). Algunas consideraciones sobre la responsabilidad civil por productos y servicios defectuosos. Portal de Información y Opinión Legal - Pontificia Universidad Católica del Perú. http://www.dike.pucp.edu.pe/doctrina/civ_art49.PDF (accessed 1 December 2020).

Fernández-Maldonado S.A, (2010). El curioso caso del consumidor 'Benjamin Button'. Actualidad Jurídica (202), 27-32. 
García Belaúnde, D., \& Eto Cruz, G. (2016). Constitución peruana. Historia y dogmática. (2 ${ }^{\text {da }}$ ed.) Adrus. Instituto Nacional de Defensa de la Competencia y de la Protección de la Propiedad Intelectual. (2005). Perú. Los intereses nacionales en defensa de la competencia y los Acuerdos Referenciales de Comercio. Serie de Publicaciones Institucionales (2). Indecopi Sello Editorial.

Stiglitz, G. (2013). Derecho y políticas de defensa del consumidor en América Latina. La experiencia colombiana. In C. L. Valderrama Rojas (Ed.), Perspectivas del Derecho del Consumo (pp. 23-32). Universidad Externado de Colombia.

Woolcott, O. (2001). La responsabilidad civil del productor de bienes y servicios en el Perú. Advocatus, 5, Universidad de Lima.

Zúñiga Palomino, M. (2010). Apuntes sobre el nuevo “Código de Defensa del Consumidor”: Por qué no era necesario, ni hará la diferencia. Actualidad jurídica, 202, 37-43.

\section{Legislation}

\section{European Union}

Council Directive 85/374/EEC on the approximation of the laws, regulations and administrative provisions of the Member States concerning liability for defective products (1985) OJ L 210.

Council Directive 93/13/EEC on unfair terms in consumer contracts (1993) OJ L 95

Directive 95/46/EEC on the protection of individuals with regard to the processing of personal data and on the free movement of such data (1995) OJ L 281.

\section{Peru}

Act No. 29733 (2011)

1993Constitution (1993)

1979 Constitution (2019)

2010 Consumer Defence and Protection Code Law no. 29571 (2010)

Decree of Law No. 25868 (1992)

Directorial Resolution No. 1530-2020-JUS / DGTAIP-DPDP (2020)

D.S. No. 036-83-JUS (1983)

Legislative Decree No. 716 (1991)

Legislative Decree No. 1045 (2008)

Peruvian Civil Code (1984)

Peru - United States of America Trade Promotion Agreement (2009)

Resolution No. 071-2014 / SPC-INDECOPI: Exp. 001-2013 / CPC-INDECOPI-CAJ (2013)

Resolution No. 0261-2014 / SPC-INDECOPI: Exp. 002-2013 / CPC- INDECOPI-CAJ (2013)

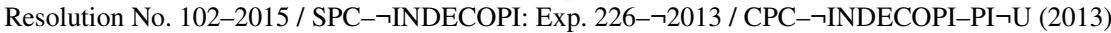

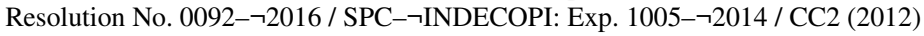

Resolution No. 078-2012/SC2-INDECOPI (2012)

Resolution No. 044-2015-JUS / DGPDP-DS (2015)

Resolution No. 088-2016-JUS / DGPDP (2016)

Resolution No. 265-2016-JUS / DGPDP-DS(2016)

STC Exp. No. 0008-2003-AI / TC (2003)

STC Exp. No. 3315-2004-AA / TC (2005)

Supreme Decree No. 024-2017-2020 (2017)

Supreme Decree No. 024-2017-2020 2017

Supreme Decree No. 036-83-JUS (1983)

Publisher's Note Springer Nature remains neutral with regard to jurisdictional claims in published maps and institutional affiliations. 